\title{
Understanding the curriculum the light of training guiding health in Brazil
}

\author{
Compreendendo os currículos à luz dos norteadores da formação em saúde no Brasil \\ Comprendiendo los currículos a la luz de los orientadores de la formación en salud en el Brasil
}

Bibiana Arantes Moraes ${ }^{1}$, Nilce Maria da Silva Campos Costa ${ }^{2}$

${ }^{1,2}$ Universidade Federal de Goiás. Goiânia, GO, Brazil

\section{ABSTRACT}

Objective: To analyze Pedagogical Projects Courses (PPCs) from the healthcare field in light of the National Curriculum Standards (NCS) policies on healthcare training. Method: exploratory descriptive study of qualitative approach, in which were carried out analyzes of PPPs of Nursing, Pharmacy, Medicine, Nutrition and Dentistry of a federal university in the Midwest region of Brazil. As technical analysis of documentary sources, adopted the content analysis in the thematic mode. Results: The analysis of PPC showed the general aspects of PPC as the course features the historical percursso and construction, professional skills and competences required for professional performance and the guiding principles of formation characterized by technical, professional practice, articulation theory/ practice, interdisciplinarity and ethical / social training. Conclusion: PPC presented is consistent with the proposals set out in DCN and carry training policies in health in Brazil, providing adequate training for health professionals, the demands of the population and the National Health System.

\section{DESCRIPTORS}

health professional; higher education; curriculum.
Correspondence Addressed to:

Bibiana Arantes Moraes

Rua 225 n 619 setor leste universitário, Goiânia,

Goiás, edifício Guaçuí, apt 604

CEP 74610-090 - Goiânia, GO, Brazil

bibiananutri20@gmail.com 


\section{INTRODUCTION}

The word curriculum comes from the Latin word curriculum, which means route or way. It represents a social, political and historical construction by institutions at a particular moment in time where they group together given knowledge in a particular area, with practices and experiences judged as important. They are then connected and used to tackle problems in society based on what is known and what has been developed ${ }^{(1,2)}$.

The syllabus, should however, go beyond being a group of instructions that need to be followed. It is the sum of all the experiences gained and lived through by the students during the course in accordance with the set objectives from the institution. Based on the objectives of institutions in the provision of education, the syllabus can have three social dimensions: what is taught, for what reason and to whom the education is being given ${ }^{(3)}$.

Syllabuses came about in Brazil based on the Cartesian philosophy of the individuality of knowledge and the fragmentation of content. Syllabuses based on disciplines are still prevalent in higher education. They are based on content and not on structured education designed in a logical and linear way which influences the training of future professionals in health care. This can demonstrate a disconnection with reality and their not being an association with the content and what is actually being understood by individuals ${ }^{(1,2)}$.

To understand the syllabuses it is necessary to understand how the subjects in them came about and the methods used in the course that is studied by students. In reality it is not possible to study syllabuses without considering their history. When this occurs, it is possible to see the connection between: schools and societies, administrations and organizational structures, educational systems and the way in which knowledge becomes both valid and subject to being replicated ${ }^{(2,4)}$.

Professional training in health care in Brazil has been historically marked by fragmentation in knowledge and a hospital centric/biologist vision. There has also been a utilization of traditional teaching models which prioritize intense specializations and procedural sophistications. This ignores fundamental pedagogical strategies in teaching and the construction of collective knowledge ${ }^{(5,6)}$.

Since the ratification of the National Syllabus Guidelines (hereafter DCN) for courses in health care between 2001 and 2004, efforts have been underway to change the professional profile so that "the proposed syllabuses should build an academic and professional profile that cover competences, skills and relevant content inside a perspective and contemporary approach pertinent to training. It also needs to be compatible with national and international references. It also must be able to: increase quality, efficiency and resoluteness in the National Health System (hereafter SUS) considering the process in the Brazilian Sanitation Reforms"(7).

The processes that bring in educational reforms generally occur through interventions made by the State. When it deems it necessary it brings in a series of actions that alter the structure and functioning of institutions. The difficulties in bringing in changes are due to the pedagogical organization of the work and the existing models of teaching in sociocultural and political contexts ${ }^{(8)}$.

Since 2003 the Ministry for Health and the Ministry for Education have been bring in persuasive policies to reform teaching in health care, such as through the National Program for the Reform of Professional Teaching in Health Care for Courses in Medicine - Promed ${ }^{(5)}$ and for all health care courses under the same program for - Pró-Saú$\mathrm{de}^{,(9)}$. Another program called the Educational Program for Work in Health Care has also started - PET -Saúde (10). The above programs involve actions which complement the DCN and the aim is to train students and or health care professionals as part of a partnership involving teaching and community service. They are also associated with research related to the needs in basic health care.

Based on the aim of promoting high quality teaching, the recommendation is for the use of interdisciplinary education mixed with contextualization and autonomy so that the students can develop skills, general competencies and specific skills to be used in health and in the economic, cultural and political structures of universities through their professors ${ }^{(4)}$.

Thus the purpose of the PPC is to give teaching institutions a social and historical platform for teaching and to provide a group of specific learning points. It should also cover: health care practices, objectives, methodological processes and evaluation criteria. The other necessity is the adequate training of health care professionals ${ }^{(2,3)}$.

The courses that are a part of the PPC ought to comply with the DCN and its accompanying policies covering health care training, both of which are necessary for professional education. The priorities are centered on: the promotion of integral care, treating people in an humane manner, being multi-professional and meeting the needs of the users of SUS. This is a move away from pre-established the curative and prescriptive approaches ${ }^{(11)}$.

Based on the above assumptions, this paper aimed to analyze the pedagogical project courses in the health care sector in light of the DCN and accompanying policies covering reform in health care training.

\section{METHOD}

The research conducted was descriptive, exploratory and qualitative in nature where courses from the PPC were analyzed in the area of health from a federal higher education institution in the mid-west region of Brazil.

We opted to conduct our studies through analyzing relevant documents, due to the history in the changing of processes and the detailed characterizations in the phenomenon that was studied. We aimed to get the most amount of information from what actually was the current state ${ }^{12,}$ 13). Whilst studying the then reality in an objective manner, we looked at the processes involved in social and cultural changes and we noted changes in the population that was 
studied. The changes were based on their structure, attitudes and social values. This also allowed for the obtaining of data at low financial costs as well as material and human resources. It also permitted the obtaining of data without inconveniencing others ${ }^{(13)}$.

This research approach that we took was important in cases where we noted trends that had not been explored in journals (just in some documents) and thus had not been the subject of analysis that would have aided in our research ${ }^{(12)}$.

The documents that we used were from the courses in the PPC which were given to us by participants at the university. The courses covered the following areas: nursing, pharmacy, medicine, nutrition and dentistry.

In order to categorize the data from the PPC we conducted a thematic analysis which involved the use of a specialist model for the analysis of content. Initially we read extensively through the relevant source documents with a view to obtaining a thorough understanding of the issues. We then started the codification process based on the documents that we were analyzing so that we could fully understand and identify meanings and so that we could structure the documents based on common characteristics. After the above steps were taken, other categories were identified and this led to data being analyzed and discussed ${ }^{(12,13}$. In order to analyze the categories, reference guides on professional training in health care was used. We also used the DCN and the accompanying policies that were in force.

The research was approved by the Ethics Committee under case number 571.173/2014 and followed the recommendations for research done on human beings. We also used consent forms for participants in the research which were explained in full to those that took part and we included a term of responsibility that was placed on us.

\section{RESULTS AND DISCUSSION}

After reading through the PPC and conducting thematic analysis on the syllabuses used, what emerged were three categories to be further analyzed that accompanied the data found in the PPC: 1) General aspects from the PPC: the creation of courses, reformulation of the syllabus, the teaching time, the structure of the syllabus, creating the PPC, methodology and evaluative process, the profile of those that don't complete the courses and course objectives, 2) The skills and competences necessary for professionals and 3) The main trainers, professional practice, technical training, theory and practice, interdisciplinary skills/approaches and ethical and social training.

\section{General Aspects of the PPC}

The courses that were studied were created between 1945 and 1975. The dates were: pharmacy and dentistry in 1945 and nutrition and nursing in 1975. All of the courses were bachelor degrees with the nursing course being a professional qualification.

With reference to the last syllabus reformulation, the pharmacy course underwent the oldest reformulation back in 2003. In 2009 the PPC for nursing and dentistry was restructured. Reformulation for nutrition courses occurred in 2013 and for medicine it was reformulated in 2014.

Knowing the historical background of the courses that were studied was important because it allowed for a better understanding of how the subjects for the courses came to be chosen. It also helped with understanding: how the courses were systemized, the state of the courses when subject to reforms and the "whys". With this in mind we were able to get a better understanding of health care training ${ }^{(3)}$.

Between 2001 and 2004 the DCN was launched for all graduate courses in the health care sector ${ }^{(6)}$. For courses in medicine the DCN was updated in $2014^{(14)}$. All the courses aimed to construct their PPC based on all of the principles of the DCN as well as its objectives and assumptions that were present in the documents ${ }^{(6)}$. Also the nutrition courses had Pró-Saúde as its guide for training. Notwithstanding the ratification of the new DCN for courses in medicine in 2014, we noted that the PPC still had general aspects from the DCN of 2001. This was due to the last approval for reform of the syllabus for the courses in medicine occurring almost at the same time as the publication of the last DCN.

We noted the influence of the persuasive policies on reforms in health education and the restructuring of the syllabus allowing for a more humanized perspective. This was in the face of demands from the syllabus and the use of SUS as a learning ground. The IES should make efforts to ensure that changes are not just epistemological. Changes in paradigms are necessary which should also include changes in actions and practices in the syllabus so that it can be effective and can train professionals for SUS ${ }^{(15)}$.

The nursing, pharmacy, nutrition and dentistry courses had structured syllabuses based on disciplines with the minimum duration being 10 semesters. The actual tuition/teaching time in classes for all of the courses was longer than 4.350 hours. The medicine courses had a syllabus based on modules with the total actual tuition/teaching time being 9144 hours and the minimum duration was 12 semesters. The total teaching time was justified based on the number of activities necessary to be completed in order to work in medicine. All of the courses were in accordance with Resolution Number 2 of the 18th June 2007 from the National Council for Education and the Higher Education Council (hereafter CNE/CES) who specify: the minimum amount of teaching hours, the payment procedures, the duration of the graduate courses, the governance for bachelor degrees and the requirement to attend classes ${ }^{(16)}$.

Based on the stablished regulations by the teaching institutions, the content of the syllabuses ought to be distributed by disciplines or modules with the same content for: general health training, specific content for each course, and content that allows the students to choose a particular area. It should also cover complementary activities for research and other courses ${ }^{(17)}$.

The DCN came about with the intention to give more autonomy for graduate course providers so that they could determine their content, methodology and evaluation process according to the reality of the teaching institution. It 
was noted that with the adoption by organizations of the discipline and/or modular approach where the same content for all courses was specified, this gave the students some freedom of chose and saw the rise of more complementary activities allowing the courses to meet the requirements. They also opened the students' horizons through their power of choice which was considered important in their training ${ }^{(7)}$.

The analyzed syllabuses had varying levels of complexity, with obligatory disciplines and complementary activities that the students could opt for. This allowed for the educational development of the students ${ }^{(11)}$.

According to the DCN and its accompanying policies in the reform of training in health care, the periods where students are supervised and where they undertake complementary activities all serve to enrich their educational development for the future. This is done through practical exercises on the courses and carrying out different activities in the class room ${ }^{(7,9,10)}$. This allows students to be well prepared to work having the know-how, the theory and the necessary practical experience. Students are developed with the ability to have both a critical and reflective mindsets (17). In the courses that we studied in the stages where the students were being supervised or where they undertook complementary activities, there was diversification in the courses, which was evidenced in the PPCs.

That which the students lived through and experienced during the courses had a strong impact on their vision of their work in the medical sector. It also influenced: how they saw the market, the way how they related to people, their professional posture and the widening of their knowledge later in their professional life ${ }^{(2,15)}$.

The documents that were analyzed required the use of certain active methodologies in the process of teaching and learning in the given course with an emphasis on continuous assessment of the student. The emphasis was on cumulative evaluations as mentioned in the $\mathrm{DCN}^{(7)}$ and change programs in training ${ }^{(9,10)}$.

When the active methodologies are used in teaching with a clearly defined output, this works to stimulate the students so that he/she: develops autonomy, becomes creative and critical and is prepared to deal with the existing problems in health care. Also when the methodologies are applied correctly, they turn out to be important tools for changes in pedagogical practices inside the IES ${ }^{(18,19)}$.

The adoption of innovative methods for teaching and learning stimulate the integration between courses and specific areas. However there are studies $(19,20)$ that show latent difficulties in the development of these methodologies as the students either finish the courses without being properly trained or the teaching methods just do not work for them. This can lead to some disciplines not having been properly dealt with in the course as well as the fragmentation of course content and a lack of knowledge in certain key areas.

That is why it is essential to have well trained professors that fully understand the available strategies/methods which will allow students to be both critical and reflective.
They will then be more aware of the importance of taking care of patients in their work, in the future ${ }^{(2,18,20)}$.

An evaluation of courses is also very important as it allows for the checking of objectives to see if they are compliant with the syllabus and the relevant demands. The process for evaluating student's learning was considered to be a continuous process and was not restricted to the final exams. At the same time courses should evaluate intellectual maturity and the best performances of the students ${ }^{(11)}$ as shown in the documents that were analyzed.

The profile of those that do not complete the courses (some professionals) and the objectives of the courses are presented both in the DCN and the accompanying policies $(7,9,10)$. We noted that the courses and the institutions aimed to educate and train health care professionals not just in technical and scientific know-how but to enable them to relate to individuals and patients on a human level.

Contrary to the studied PPC in this study, another study showed that the profile of professionals that did not complete these courses showed that they were not committed to the profession in working in SUS. SUS has a lack of those considered to be multi-professional and those that are able to treat people with dignity. This means that these courses often produce unprepared people ${ }^{(21)}$.

The above study argued that higher education in health care in Brazil still presents difficulties that need to be overcome, such as a lack of knowledge and commitment to SUS and a lack of understanding about working in multi-professional teams. Other problems included: a deficiency in the integration of interdisciplinary knowledge, turning out professionals with little maturity to exercise their profession and resistance to change. Other difficulties exist that perpetuate the status quo in health care ${ }^{(21)}$.

Another characteristic found that was a part of the PPC was the relevance given to the academic community in the process of creating the syllabus. Only the nursing courses did not take the approach of its creation being done with participants from the PPC. Students, the teaching staff and technical administrators ought to understand their role as agents of change so that they can contribute to the drafting of syllabuses. They should also be able to promote the development of good health care professionals for SUS based on the challenges that exist ${ }^{(20,22,23)}$.

\section{SKILlLS AND COMPETENCES}

In Brazil the DCN stipulate the skills and competences that are necessary for health care professionals to have. The use of syllabuses based on competences was taken on board by the national and international academic community so that the above could be acquired by students as well as acquiring technical and scientific knowledge ${ }^{(11,24)}$.

The DCN prioritizes general skills and competences for health care professionals: 1) Developing students to act in the areas of prevention, promotion, protection and rehabilitation in health care. 2) Developing the ability to take decisions based on evaluation and systemization and to decide the best course of action based on scientific evidence. 3) Developing the student's communication skills which 
facilitate good dialogue with patients and the ability to be competent in at least one foreign language. 4) The ability to lead in multi-professional groups and take decisions when necessary. 5) The ability to deal with administrative work. 6) Recognizing the need for continuous education throughout the life of the professional ${ }^{(7)}$.

We checked whether the DCN was used in the creation of all of the PPCs that were analyzed as all of the skills and general competences were present. We looked at the specifics of the professional training. They could be considered fundamental in the changing of teaching methods. Research which analyzed 10 courses from the PPC for nursing, observed the presence of all of the competences and skills that were expected and which were compliant with the syllabus ${ }^{(11)}$.

A study carried out with nurses from an educational center noted that the following skills and competences were difficult to be achieved for those that eventually left the course: leadership, administration and management and continuous learning. They are related in that health care professionals may have to lead teams and should be responsible for their own educational development ${ }^{(25)}$.

The teaching institutions ought to execute practices which seek to develop all of the required skills and competences in the $\mathrm{DCN}^{(7)}$. The formalization of health care education based on skills and competences is the basis of syllabuses and the idea is to galvanize professors to teach students how to do, to care and to understand in the context of health. They need to understand that true learning comes from having day to day contact with patients ${ }^{(20)}$.

\section{THE OVERARCHING OBJECTIVES OF EDUCATION AND TRAINING IN HEALTH CARE}

The PPCs that were studied covered the overarching objectives in education and training for professionals in health covering: professional practice, technical training, the teaching of theory and practice, interdisciplinary education and education covering ethical and social issues. All of these were evidenced inside the DCN and its accompanying policies and are considered important in higher education institutions ${ }^{(7,9,10)}$.

The PPC stipulates that from the very outset of the course students should be undertaking practical activities so that they are near to real life experiences. They should be in activities where the level of complexity increases as well as their autonomy ${ }^{(7,20)}$.

The use of professional practical exercises shows how important the training process is. The idea of practical training in a real health care context came from the SUS school network and only became possible through governmental incentives such as the $\mathrm{DCN}^{(7)}$ and its accompanying policies ${ }^{(9,10)}$. There are differences between reality and what was placed in the legislation and policies, but professional practice has become ever more important in the training of students ${ }^{(26)}$.

Changes in the syllabus for health are based on the DCN and will only occur when value is placed on understating the basic health care needs of the population. Basic/
Primary health care in Brazil covers $80 \%$ of all health care problems and that is why this area needs to be a priority in health care ${ }^{(4)}$.

We noted in the PPCs that technical training took place due to the content of the syllabuses. The students receive practical training and are given the benefit of innovative methodologies and the use of technologies.

The insertion of students in real life situations and using interdisciplinary actions promotes the coming together of theory and practice which in turn means that they leave higher education being: autonomous, intelligent and ready to enter the market in a professional capacity $(7,9,10,26)$.

A study carried out on the training given to doctors for the Family Health Strategy (hereafter ESF) noted from those that have completed their training over the last two years that many: could not work in teams, could not carry out prevention activities, were unable to associate what they learnt with reality, and were unprepared to work in basic health care centers. Those that have been trained through the use of the current syllabus (based on the DCN and the accompanying policies) thought that their training met the needs associated with primary health care through the different disciplines. This information highlighted the importance of the DCN and its accompanying policies in the creation of a syllabus which should meet the health needs of the population ${ }^{(27)}$.

The PPC proposes integration between theory, practice and interdisciplinary approaches through the diversification of scenarios for learning. It also advocates: specific teaching methods and it encourages professionals to widen their knowledge base.

It is important to note that in spite of the above proposals for the syllabus which covers course integration, amongst other things, the syllabus also encourages inclusiveness and sharing, although this does not always occur in practice. As a result there is often little integration between professionals in teams in the work place ${ }^{(21)}$.

In spite of the relative aspects in technical training and the articulation between theory and practice (as well as an interdisciplinary approach), this approach is expressly encouraged in the PPC and they are considered to be amongst the biggest challenges in health care training ${ }^{9}$, 10). Where there are poor levels of teaching and fragmentations in knowledge (particularly in basic sciences) in relation to professionals, it makes it difficult for the stipulations in the syllabuses to be carried out ${ }^{(28,29)}$.

The PPC advocates the importance of ethical and social training so that professionals can work providing a high quality of care. For example the dentistry courses consider ethical and social education to be of equal importance as technical training. A study showed that health care professionals agreed on the relevance of ethical training for working in basic primary health care units ${ }^{(30)}$. On the other hand studies have shown that in spite of the PPC's importance on ethical and social training, the courses can devalue such disciplines which tackle these issues.

Good interaction is also needed where there is a mixed of teaching and the actually provision of services. This is 
because being technically competent does not necessarily mean that a professional knows how to treat an individual. The health service provides opportunities for its students to put theory into practice and its training is specifically geared towards SUS ${ }^{(15,29)}$.

The PPC should not only promote practices that cover technical knowledge, competences and skills which can be acquired through innovative training, but emphasis should be placed on the provision of general care that reflects ethics and takes a more humanist approach ${ }^{(24,26)}$.

Technical training only creates professionals with technical and scientific knowledge but many professionals trained in this way do not understand how to treat individuals as people. This needs to be changed to improve health care training for SUS ${ }^{(21)}$.

In order to overcome the challenges that exist in health care training in Brazil, pedagogical projects are needed to illustrate the ideal profile of a health care professional. Also syllabuses need to be more aligned with the principles of SUS and this should be done on an official basis ${ }^{(20)}$.

\section{CONCLUSION}

The courses from the PPC that were a part of this study met the general requirements in the DCN and its accompanying policies. This is done through innovated teaching methods that aim to train health care professionals with general knowledge. They are also taught to be critical, reflective, to work in teams and the students are given workplace experience early on in their courses. This allows them to progress to deal with more complex issues. The idea is to develop competences and skills needed in health which will meet the demands of the population.

Health care training is guided by the Pedagogical Project Courses but it is essential that everything that is mentioned in the PPC is actually put into practice so that their objectives are reached. The syllabuses, apart from being aligned to the overarching guidance for teaching in health care, should also address the concerns of the academic community because they are the ones that create the training courses for health care in Brazil.

In spite of this study having worked with the PPC as a source of information, we do not believe that analysis in this area should be limited to these documents. It should also extend to take on board the views of the academic community in general and professionals in the provision of health care services so that a more rounded vision of health care education can be obtained.

\section{CONFLICT OF INTEREST}

There were no conflicts of interest in the research that we conducted.

\section{SOURCES OF FINANCES}

The research that we conducted was subsidized by the National Council for Scientific and Technological Development- CNPq and support of Higher Education Personnel Improvement Coordination - CAPES, the Brazilian Government for the qualification of human resources.

\section{RESUMO}

Objetivo: analisar os Projetos Pedagógicos de Cursos (PPC) da área da saúde à luz das Diretrizes Curriculares Nacionais (DCN) e das políticas indutoras de formação em saúde do Brasil. Método: pesquisa descritiva exploratória de abordagem qualitativa, na qual foram realizadas análises dos PPC dos cursos de Enfermagem, Farmácia, Medicina, Nutrição e Odontologia de uma instituição federal de ensino superior da região Centro-Oeste do Brasil. Como técnica de análises das fontes documentais, adotou-se a análise de conteúdo, na modalidade temática. Resultados: as análises dos PPC evidenciaram os aspectos gerais dos PPC como as características do curso, o percursso histórico e sua construção, habilidades e competências profissionais requeridas para o desempenho profissional e os princípios norteadores da formação caracterizados pela técnica, prática profissional, articulação teoria/prática, interdisciplinaridade e formação ética/social. Conclusão: os PPC apresentaram-se condizentes com as propostas previstas nas DCN e com as políticas indutoras de formação em saúde do Brasil, proporcionando a formação adequada para os profissionais de saúde, as demandas da população e do Sistema Único de Saúde.

\section{DESCRITORES}

Profissional de saúde; educação superior; currículo.

\section{RESUMEN}

Objetivo: Analizar Proyectos Pedagógicos de Curso (PPC) de la salud a la luz de las Directrices Curriculares Nacionales (DCN) y la inducción de la formación de las políticas de salud en Brasil. Método: Estudio descriptivo exploratorio de abordaje cualitativo, en el cual se llevaron a cabo análisis de las PPC de Enfermería, Farmacia, Medicina, Nutrición y Odontología de la Universidad Federal de la región del Medio Oeste de Brasil. Como el análisis técnico de las fuentes documentales, adoptado el análisis de contenido en la modalidad temática. Resultados: El análisis de PPC mostraron los aspectos generales de la PPC como el curso cuenta con el percursso histórico y la construcción, las habilidades y las competencias profesionales requeridas para el desempeño profesional y los principios rectores de la formación se caracteriza por técnica, práctica profesional, la teoría de la articulación / práctica, la interdisciplinariedad y la formación ética / social. Conclusión: PPC presentada es consistente con las propuestas que figuran en el DCN y llevar a las políticas de formación en materia de salud en Brasil, proporcionando una formación adecuada para los profesionales de la salud, las demandas de la población y el Sistema Único de Salud.

\section{DESCRIPTORES}

Profesional de salud; educación superior; currículo. 


\section{REFERENCES}

1. Albuquerque SA, Batista RS, Tanji S, Moço ETM. Currículos disciplinares na área de saúde: ensaio sobre saber e poder. Interface. 2009; 13(31): 261-272.

2. Maia JA. O currículo no ensino superior em saúde. In: Batista NA, Batista SH. Docência em saúde: temas e experiências. 2.ed. São Paulo: Senac, 2014. p. 101-133.

3. Braccialli LAD, M. Oliveira AC. Concepções de avaliação de desempenho de um currículo orientado por competência. Rev. Esc. Enferm. USP. 2011; 45(5): 1221-1228.

4. Bravo VAA, Cyrino EG, Azevedo MAR. Ensino na atenção primária à saúde e as Diretrizes Curriculares Nacionais: o papel do projeto político-pedagógico. In: Cyrino AP, Godoy D, Cyrino EG. Saúde, ensino e comunidade: reflexões sobre práticas de ensino na atenção primária à saúde. São Paulo: Cultura acadêmica; 2014. p. 25-48.

5. Gonzalez AD, Almeida MJ. Movimentos de mudança na formação em saúde: da medicina comunitária às diretrizes curriculares. Physi. 2010; 20(2): 551-570.

6. Haddad AE, Morita MC, Pierantoni CR, Brenelli SL, Passarella T, Campos FE. Formação de profissionais de saúde no Brasil: uma análise no período de 1991 a 2008. Rev. Saúde Pública. 2010; 44(3): 389-393.

7. Brasil. Parecer $n^{\circ} 1.133$ de 7 de outubro de 2001. Dispõe as Diretrizes Curriculares para os cursos de graduação de Enfermagem, Farmácia, Medicina, Nutrição e Odontologia. Brasília: Ministério da Saúde/Educação; 2001.

8. Silva MR. Currículo e formação humana: racionalidade e adaptação. São Paulo: Cortez editora, 2008. Currículo e competências: a formação administrativa. p. 23-41.

9. Brasil. Portaria interministerial no 3.019 de 26 de novembro de 2007. Dispõe sobre o Programa Nacional de Reorientação da Formação Profissional em Saúde Pró-Saúde para os cursos de graduação da área da saúde. Diário Oficial da União, Brasília: Ministério da Saúde/Educação; 2007.

10. Brasil. Portaria interministerial n ${ }^{\circ} 1.802$, de 26 de agosto de 2008. Institui o Programa de Educação pelo Trabalho para a Saúde - PET-saúde. Diário Oficial, Brasília: Ministério da Saúde/Educação; 2008.

11. Kloh D, Reibnitz KS, Boehs AE, Wosny AM, Lima MM. Princípio da integralidade do cuidado nos projetos políticos-pedagógicos dos cursos de Enfermagem. Rev. latinoam. enferm. 2014; 22(4): 693-700.

12. Minayo MCS. O desafio do conhecimento: pesquisa qualitativa em saúde. 14.ed. São Paulo: Hucitec, 2014.

13. Sá-Silva J R, Almeida CD, Guindani JF. Pesquisa documental: pistas teóricas e metodológicas. Rev. Bras. Hist. Cien. Sociais. 2009; 1(1): 01-15.

14. Brasil. Portaria interministerial $n^{\circ} 116$, de 3 de abril de 2014. Dispõe as Diretrizes Curriculares para o curso de graduação de Medicina. Brasília: Ministério da educação/saúde; 2014.

15. Silveira JLGC, Garcia VL. Curricular change within dentistry: meanings according to the subjects of the learning. Interface. 2015; 19(53): 145-158.

16. Brasil. Resolução $n^{\circ}$ 2, de 18 de junho de 2007. Dispõe sobre carga horária mínima e procedimentos relativos à integralização e duração dos cursos de graduação, bacharelados, na modalidade presencial. Diário Oficial da União, Brasília: Senado; 2007.

17. Ufg. Universidade Federal de Goiás. Conselho de ensino, pesquisa, extensão e cultura da Universidade Federal de Goiás. Resolução - CEPEC no 1122 de 9 de novembro de 2012. Aprova o novo Regulamento Geral dos Cursos de Graduação (RGCG) da Universidade Federal de Goiás e revoga as disposições em contrário. UFG; 2012.

18. Marran AL, Lima PG, Bagnato MHS. As políticas educacionais e o estágio curricular supervisionado no curso de graduação em enfermagem. Trab. educ. saúde. 2015; 13(1): 89-108.

19. Costa MV, Borges FA. O Pró-PET-Saúde frente aos desafios do processo de formação profissional em saúde. Interface. $2015 ; 19$ (1s): $753-763$.

20. Tonhom SFR, Costa MCG, Hamamoto CG, Francisco AM, Gomes R. A formação em enfermagem por área de competência: limites e possibilidades. Rev. Esc. Enferm. USP. 2014; 48(2s): 225-232.

21. Almeida Filho NM. Contextos, impasses e desafios na formação de trabalhadores em saúde coletiva no Brasil. Ciênc. saúde coletiva. 2013; 18(6): 1677-1682.

22. Oliveira BRG, Schneider JF, Rizzotto MLF, Rodrigues RM. Avaliação e construção de um projeto político pedagógico para a graduação em enfermagem. REBEN. 2003; 56(4): 369-373.

23. Silva VO, Santana PMMA. Conteúdos curriculares e o Sistema Único de Saúde (SUS): categorias analíticas, lacunas e desafios. Interface. 2015; 19(9): 44-56.

24. Donoff M, Lawrence K, Allen T, Brailovky C, Crichton T, Bethune C, Laughlin T, Wetmore S. Defining competency-based evoluation objectives in family medicine. Can. Fam. Physician. 2012; 58(4): 596-604.

25. Sade PMC, Peres AM. Developmente of nursing management competencies: guidelines for contínuos education services. Rev. Esc. Enferm. USP. 2015; 49(6): 991-998.

26. Celedônio RM, Jorge MSB, Santos DCM, Freitas CHA, Aquino FOTP. Políticas de educação permanente e formação em saúde: uma análise documental. Rev. RENE. 2012; 13(5): 1100-1110.

27. Nóbrega-therrien SM, Souza PMM, Pinheiro FMC, Castro VS. Profissional no SUS: o papel da atenção básica em saúde na perspectiva docente. Rev. Bras. Educ. Médica. 2015; 39(1): 112-118.

28. Hora DL, Erthal RMC, Souza CTV, Hora EL. Propostas inovadoras na formação do profissional para o Sistema Único de Saúde. Trab. educ. saúde. 2013; 11(3): 471-486.

29. Biscarde DGS, Pereira-Santos M, Silva LB. Formação em saúde, extensão universitária e Sistema Único de Saúde (SUS): conexões necessárias entre conhecimento e intervenção centradas na realidade e repercussões no processo formativo. Interface. comum. saúde educ. 2014; 18(48): 177-186.

30. Witt RR, Roos MO, Carvaho NM, Silva AM, Rodrigues CDS, Santos MT. Competências profissionais para o atendimento de idosos em Atenção Primária à Saúde. Rev. Esc. Enferm. USP. 2014; 48(6): 1020-1025. 


\section{ACKNOWLEDGEMENTS}

We would like to thank the Teaching Institution (Instituição de Ensino) and those that coordinate the courses there, for having made available to us the PPCs which we used in this paper. 